\title{
Effective treatment for malignant mediastinal teratoma
}

\author{
D PARKER, CP HOLFORD, RHJ BEGENT, ES NEWLANDS, GJS RUSTIN, AR MAKEY, \\ KD BAGSHAWE
}

From the Departments of Medical Oncology and Cardiothoracic Surgery, Charing Cross Hospital, London

\begin{abstract}
Primary malignant mediastinal teratoma is a rare tumour previously regarded as inevitably fatal. In a series of eight male patients with a mean age of 24 years five remain alive and well. All patients showed raised serum concentrations of human chorionic gonadotrophin or $\alpha$ fetoprotein. The patients were treated with intermittent combination chemotherapy that included cisplatin. Six patients responded to chemotherapy with a fall in human chorionic gonadotrophin or $\alpha$ fetoprotein to near normal levels and they then had radical excision of the remaining tumour. Living malignant tumour was found in four of the specimens and these patients received postoperative chemotherapy. One patient died after eight months and the remaining five patients are alive and well 13-136 months after the start of treatment. The two patients who did not undergo surgery died at one month and 15 months. Intermittent combination chemotherapy and carefully timed radical excision of these tumours would appear to have produced better results than have been reported in other series.
\end{abstract}

This paper describes a treatment for primary mediastinal teratoma which may result in cure of this tumour, previously regarded as inevitably fatal. The use of $\alpha$ fetoprotein and human chorionic gonadotrophin assays is emphasised as providing a powerful discriminatory test for malignant teratoma in patients with mediastinal masses.

It has been suggested that mediastinal teratomas arise in the thymus from primordial germ cell rests that have failed to migrate from the endodermal germinal epithelium. ${ }^{1}$ Mediastinal germ cell tumours resemble those of the testis. Eighty per cent are benign teratomas ${ }^{2}$ and can usually be excised; they show a bizarre mixture of mature tissues. Most are cystic and were formerly described as "dermoid cysts." A particular feature of the benign mediastinal teratoma may be the presence of mature pancreatic tissue.' Seminomas show characteristic uniform sheets of cells and are curable by radiotherapy, provided that they are limited in extent. ${ }^{3-5}$ Malignant teratomas include elements of mature (benign) teratoma, immature teratoma, choriocarcinoma, yolk sac carcinoma, embryonal

\footnotetext{
Address for reprint requests: Dr D Parker, Bradford Royal Infirmary, Bradford BD9 6RJ.
}

Accepted 17 August 1983 carcinoma, and seminoma in various proportions. They are distinguished from pure seminoma and benign teratoma by their histological appearance and by their production of $\alpha$ fetoprotein and human chorionic gonadotrophin. The response to surgery and radiotherapy has been poor.

All assessments of the frequency of malignant mediastinal teratoma are biased by the particular renown and interest of the hospital concerned, but everyone agrees that they are rare. Schlumberger' reported 16 cases of mediastinal teratoma in "several million" recruits to the United States Armed Forces. Eleven per cent of mediastinal masses are due to germ cell tumours and $13-30 \%$ of these are malignant. ${ }^{26}$ The tumour is virtually restricted to men, with only isolated reports of the disease in women. ${ }^{7}$

The encouraging results of an approach using chemotherapy and surgery in the treatment of malignant mediastinal teratoma are reported and contrasted with previous experience.

\section{Patients and assessment of disease}

There were eight patients with primary mediastinal teratoma in this series. They were all young men or boys, with a mean age of 24 years (range 11-42). 
Three patients have already been reported. ${ }^{8}$ Presenting symptoms were a persistent cough, gynaecomastia, dyspnoea, and pain in the chest, shoulder, or back. The diagnosis was established by needle biopsy in conjunction with measurements of human chorionic gonadotrophin and $\alpha$ fetoprotein. In three patients a parasternal mediastinotomy had been performed before referral to this hospital. All the patients showed raised concentrations of either human chorionic gonadotrophin or $\alpha$ fetoprotein or both. Gynaecomastia was present in two of the four patients with raised serum human chorionic gonadotrophin concentrations.

Alpha fetoprotein and human chorionic gonadotrophin concentrations were measured twice weekly during treatment and thereafter at greater intervals. Computed tomography was carried out to assess the extent of the tumour or of spread to other organs and it was repeated after marker values had become normal or stabilised. Other investigations included bone and liver isotope scans, plain radiographs of the chest and abdomen, and assessment of renal and hepatic function.

\section{Chemotherapy and surgical treatment}

Patients before 1976 received the treatment then in use for gestational choriocarcinoma and were treated with vincristine, methotrexate, cyclophosphamide and actinomycin D. ${ }^{8}$ The regimen used latterly was described by Newlands et al ${ }^{9}$ (table 1). Patients who were in respiratory failure received an infusion of cisplatin $\left(20 \mathrm{mg} / \mathrm{m}^{2}\right.$ intravenously) and etoposide $\left(100 \mathrm{mg} / \mathrm{m}^{2}\right.$ intravenously) on days 1,2 , and 3 , repeated after six days before they started the standard treatment. Chemotherapy was continued for an average of 18 weeks (seven courses) before operation.
No chemotherapy was given for about 14 days before surgery. Support treatment included transfusions of blood, platelets, and fresh frozen plasma. Sputum and nasal and throat swabs were cultured and prophylactic penicillin $600 \mathrm{mg}$ and flucloxacillin $500 \mathrm{mg}$ were given intramuscularly six hourly for one week from the time the premedication was given. Methotrexate $50 \mathrm{mg}$ was also given intravenously with the premedication to protect the patient against tumour dissemination during surgery.

\section{Results}

Seven of the eight patients showed a definite clinical improvement during chemotherapy, with a decisive fall in concentrations of the tumour markers $\alpha$ fetoprotein and human chorionic gonadotrophin (table 2, figs 1 and 2). In two of the patients who responded to chemotherapy the markers fell to undetectable levels before surgery.

Five patients received sequential combination chemotherapy including cisplatin. The two patients who failed to respond to combinations containing cisplatin and who subsequently died had been extensively treated with other chemotherapy before referral.

When patients had achieved their maximum response to chemotherapy, as judged by clinical examination and radiological assessment and by the appearance of steady concentrations of the tumour markers, they were referred for surgical excision of the residual mass. Of the six patients in this group, four were given from three to five courses of chemotherapy after operation because malignant tissue was found in the resected specimen.

The mediastinal lesions were resected through a median sternotomy in one patient and by an extended anterolateral thoracotomy in five patients.

\section{Table 1 Chemotherapy regimen for malignant teratoma (Newlands et al ${ }^{9}$ )}

TREATMENT A

Day $I$

Vincristine $1.0 \mathrm{mg} / \mathrm{m}^{2}$ intravenously 10 am

Methotrexate $100 \mathrm{mg} / \mathrm{m}^{2}$ intravenously statim $1 \mathrm{pm}$ followed by methotrexate $200 \mathrm{mg} / \mathrm{m}^{2}$ intravenously as a $12 \mathrm{hour}$ infusion

Day 2

Bleomycin $15 \mathrm{mg}$ given as a 24 hour infusion

Folinic acid rescue started at $3 \mathrm{pm}$ in a dose of $15 \mathrm{mg} 12$ hourly, four doses

Day 3

Bleomycin infusion $15 \mathrm{mg}$ by 24 hour infusion

Forced diuresis with mannitol and hydration at the rate of 1 litre hourly given for three hours before:

Cisplatin $120 \mathrm{mg} / \mathrm{m}^{2}$ given as a short intravenous infusion and the diuresis continued at 1 litre hourly for a further three hours with mannitol. Hydration continued until the patient stops vomiting

TREATMENT B

Etoposide $100 \mathrm{mg} / \mathrm{m}^{2}$ intravenously days $1-5$

Actinomycin D $0.5 \mathrm{mg}$ intravenously days 3,4 , and 5

Cyclophosphamide $500 \mathrm{mg} / \mathrm{m}^{2}$ intravenously day 5

Treatments are given at 10 day intervals if blood counts permit, alternating as follows: A, A, B, A, B, A, B, etc. Cisplatin is omitted from later treatments if the response is good. Potassium and magnesium supplements are given with the hydration regimen. 
Table 2 Change in concentrations of tumour markers after chemotherapy and surgery

\begin{tabular}{|c|c|c|c|c|c|}
\hline \multirow[t]{2}{*}{ Patient No } & \multirow[t]{2}{*}{ Marker* } & \multicolumn{3}{|c|}{ Serum concentration of marker* } & \multirow[t]{2}{*}{ Survival (months) } \\
\hline & & Before treatment & After chemotherapy & After surgery & \\
\hline $\begin{array}{l}1 \\
2 \ddagger \\
3 \\
4 \\
5 \\
6 \\
7 \ddagger \\
88\end{array}$ & $\begin{array}{l}\text { HCG } \\
\text { AFP } \\
\text { AFP } \\
\text { HCG } \\
\text { AFP } \\
\text { HCG } \\
\text { AFP } \\
\text { HCG } \\
\text { AFP }\end{array}$ & $\begin{array}{c}44 \times 10^{3} \\
1.2 \times 10^{3} \\
4.1 \times 10^{3} \\
998 \times 10^{3} \\
350 \\
1.4 \times 10^{3} \dagger \\
4.0 \times 10^{3} \\
710 \\
400\end{array}$ & $\begin{array}{l}0 \\
80 \\
54 \\
10 \\
45 \\
2 \dagger \\
5.0 \times 10^{3} \\
2.0 \times 10^{3}\end{array}$ & $\begin{array}{c}0 \\
80 \\
0 \\
0 \\
15 \\
1 \dagger \\
\text { No surgery } \\
\text { No surgery }\end{array}$ & $\begin{array}{l}\text { 88: alive } \\
\text { 8: dead } \\
\text { 45: alive } \\
\text { 23: alive } \\
\text { 13: alive } \\
\text { 136: alive } \\
\text { 15: dead } \\
\text { 1: dead }\end{array}$ \\
\hline
\end{tabular}

"HCG - human chorionic gonadotrophin, IU/1; AFP— $\alpha$ fetoprotein, kU/l.

tUrine value.

$\ddagger$ Extensive treatment before referral.

$\S$ Early death from extensive disease.

The objective was to remove the tumour completely, and if this was not possible to remove the bulk of the primary tumour and any metastatic tumour tissue that was accessible. Complete removal, as judged macroscopically, was achieved in five of the six patients (table 3).

Although extensive adhesions were encountered between the tumour and pericardium, chest wall, and lung they did not prevent excision, but they did result in considerable blood loss, the average loss being $1700 \mathrm{ml}$. The postoperative complications were few, given the scale of the surgery performed. This was probably because the patients were young and the disease had regressed with chemotherapy, resulting in a plane of cleavage between the tumour and vital structures. In one patient there was a persistent air leak lasting four weeks, due to reduced healing of small bronchi on the raw surface of the lung. Wound infection with superficial dehiscence developed in two patients. No major dehiscence occurred and this may be attributed to the use of nylon pericostal sutures.

In one patient a second thoracotomy was carried out nine years after the initial operation because of an enlarging shadow on the chest radiograph. In a second patient surgery was delayed for six years after chemotherapy and was also performed because of an enlarging shadow on the chest radiograph. In both these cases mature teratoma was found. In four other patients, in whom excision was performed immediately after chemotherapy, malignant elements were still present (table 3 ). All these patients received postoperative chemotherapy.

Five patients are alive from 13 to 136 months after diagnosis (tables 2-4).

\section{Discussion}

The most important finding in this series of young patients is that primary malignant mediastinal teratoma is potentially curable with appropriate treatment. Good results depend on early diagnosis followed by intensive chemotherapy and radical surgical excision.

The fact that mediastinal teratoma occurs in men and may be associated with Klinefelter's syndrome $^{2627}$ or gynaecomastia may strengthen suspicion in some cases. Serum $\alpha$ fetoprotein and human chorionic gonadotrophin concentrations are likely to be raised if a malignant teratoma is present; all the patients in the present series showed raised concentrations of at least one tumour marker and one patient showed raised concentrations of both. Economou $e t a^{25}$ also found that all nine of their patients with malignant mediastinal teratoma showed increased concentrations of markers. Needle biopsy or mediastinotomy will then give a definitive histological diagnosis.

It may be difficult to exclude the possibility that a mediastinal teratoma has arisen as a metastatic tumour from a testicular or retroperitoneal primary tumour. The presence of a testicular teratoma and a mediastinal mass suggests that the tumour arose in the testis, but metastases and metachronous tumours in the testis have been recorded. ${ }^{28}$ In practical terms the origin of a mediastinal teratoma is mainly of academic interest. Full staging should be carried out at presentation, with particular reference to the retroperitoneal areas and testes. If resistance to treatment is encountered a residual mass of tumour outside the mediastinum should be sought, but this has not occurred in our experience.

The importance of starting appropriate treatment quickly merits emphasis. On the one hand continued single agent treatment may merely induce drug resistance, but on the other hand aggressive treatment in the face of respiratory failure may worsen the patient's condition owing to oedema in lysing tumour. Our policy of starting treatment with an infusion of cisplatin and etoposide in patients with 

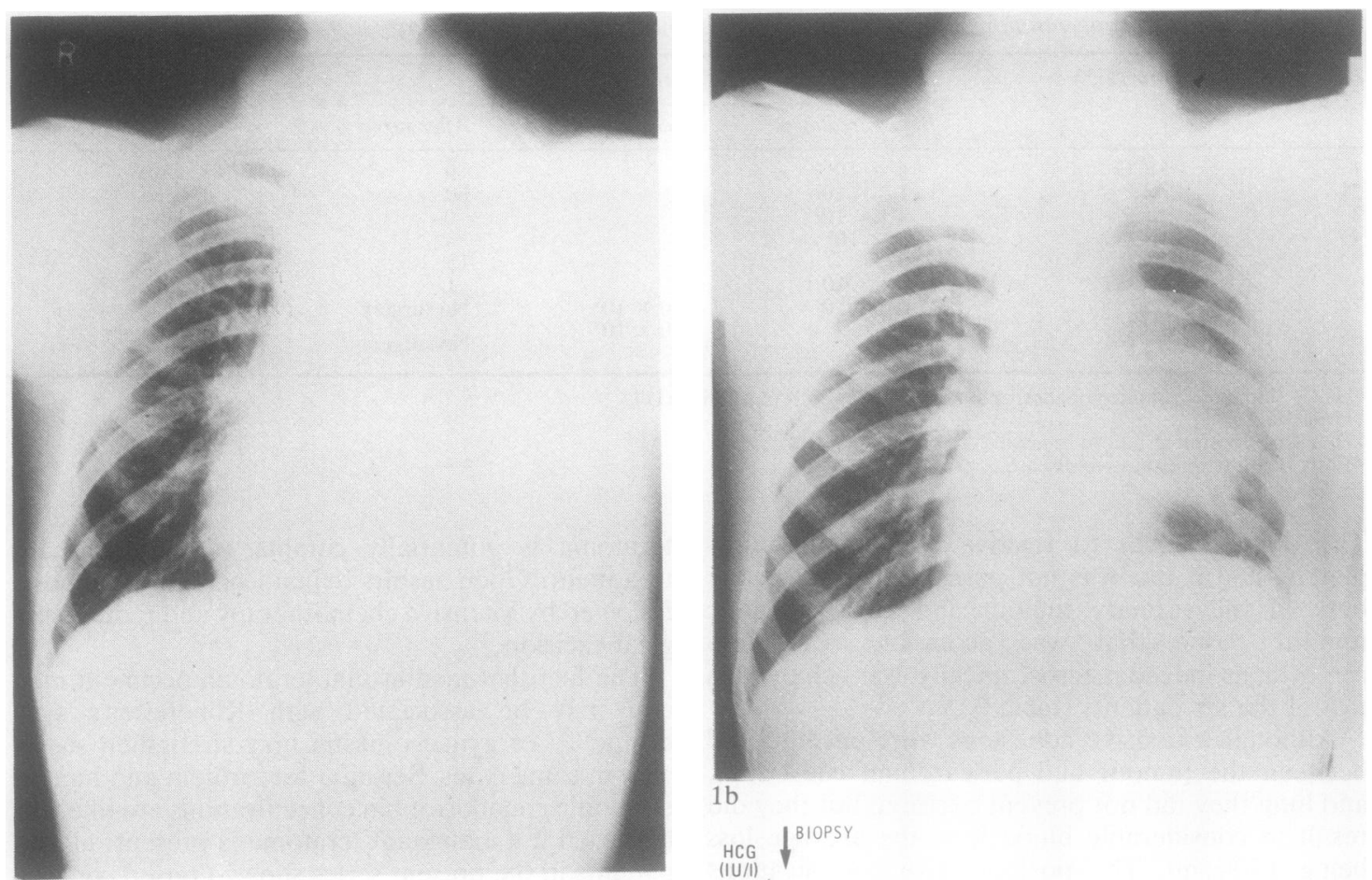

$1 \mathrm{a}$
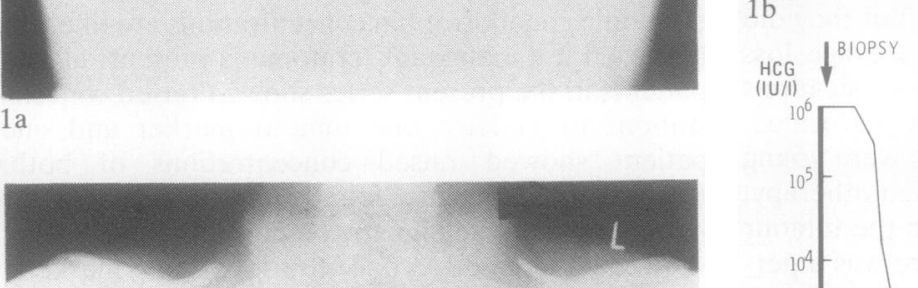

Fig 2 Response to treatment in a patient (No 4, aged 24 years) with a mediastinal teratoma producing human chorionic gonadotrophin. HCG-human chorionic gonadotrophin (concentration in blood); MTX-

Fig 1 Patient 5: chest radiographs (a) before and (b) after chemotherapy showing a large mediastinal teratoma extending into the left lung, and (c) after surgery . methotrexate; IT -intrathecal. $\square$ Etoposide, cisplatin; vincristine, methotrexate, bleomycin, cisplatin; - etoposide, actinomycin D, cyclophosphamide. 
Table 3 Tumour marker concentrations, operative findings, and postoperative chemotherapy

\begin{tabular}{|c|c|c|c|c|c|c|}
\hline \multirow{3}{*}{$\begin{array}{l}\text { Patient } \\
\text { No }\end{array}$} & \multicolumn{4}{|c|}{ Concentration of marker } & \multirow{3}{*}{ Operative fundings } & \multirow{3}{*}{$\begin{array}{l}\text { Postoperative } \\
\text { chemotherapy }\end{array}$} \\
\hline & \multicolumn{2}{|l|}{ Preoperative } & \multirow{2}{*}{$\frac{\text { Postoperative }}{H C G(I U / l)}$} & & & \\
\hline & HCG (IU/l) & $A F P(K U / l)$ & & $A F P(K U / l)$ & & \\
\hline 1 & $<1$ & & $<1$ & & $\begin{array}{l}\text { Mature encapsulated tumour, fully } \\
\text { removed }\end{array}$ & Nil \\
\hline 2 & & 80 & & 80 & $\begin{array}{l}\text { Malignant tissue present, partly } \\
\text { removed }\end{array}$ & 3 courses \\
\hline 3 & & 54 & & 0 & $\begin{array}{l}\text { Malignant tissue present, fully } \\
\text { removed }\end{array}$ & 3 courses \\
\hline 4 & 10 & & 0 & & $\begin{array}{l}\text { Necrotic tumour present, fully } \\
\text { removed }\end{array}$ & 5 courses \\
\hline 5 & & 45 & & 15 & $\begin{array}{l}\text { Incomplete resection of malignant } \\
\text { tumour }\end{array}$ & 5 courses \\
\hline 6 & 2 & & 1 & & Complete resection of mature tumour & Nil \\
\hline
\end{tabular}

HCG-human chorionic gonadotrophin; AFP- $\alpha$ fetoprotein.

respiratory difficulties has so far been successful.

Surgery was undertaken when it was judged that the response to chemotherapy was maximal. Chemotherapy before operation reduces tumour bulk and makes surgery feasible, but the difficulty of complete surgical excision should be emphasised, as an adherent fibrous tissue reaction is commonly found. Despite this the surgical complications have been temporary.

Alpha fetoprotein and human chorionic gonadotrophin concentrations provide valuable information for diagnosis, for assessment of response to treatment, and for prognosis. A fall in $\alpha$ fetoprotein or human chorionic gonadotrophin to undetectable levels before operation correlated with the surgical finding of well encapsulated tumours which could be excised completely and which showed differentiated tumour on histological examination (table 3). By contrast, malignant tissue was found in the four patients whose tumour concentrations failed to return to normal before operation, and they received postoperative chemotherapy. We found that a fall in marker concentrations to normal after chemotherapy and surgery correlated with long survival, while the three patients whose $\alpha$ fetoprotein or human chorionic gonadotrophin failed to fall died within 15 months. Two of these patients did not undergo operative excision because of an inadequate response to chemotherapy. It is notable that the three patients who died in this series had high $\alpha$ fetoprotein concentrations at presentation, which suggests that the yolk sac element is more resistant to treatment.

Length of survival in patients with testicular teratoma has been shown to correlate with human chorionic gonadotrophin or $\alpha$ fetoprotein concentra-

Table 4 Survival of patients with mediastinal teratoma

\begin{tabular}{|c|c|c|c|c|c|}
\hline \multirow[t]{2}{*}{ Authors } & \multirow{2}{*}{$\begin{array}{l}\text { Year of } \\
\text { publication }\end{array}$} & \multicolumn{2}{|c|}{$>12$ months } & \multicolumn{2}{|c|}{$\leqslant 12$ months } \\
\hline & & Alive & Dead & Alive & Dead \\
\hline 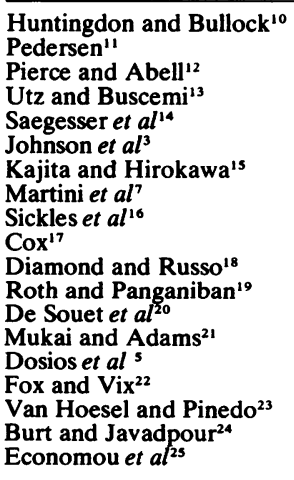 & $\begin{array}{l}1970 \\
1970 \\
1970 \\
1971 \\
1972 \\
1973 \\
1973 \\
1974 \\
1974 \\
1975 \\
1976 \\
1976 \\
1977 \\
1979 \\
1980 \\
1980 \\
1980 \\
1981 \\
1982\end{array}$ & $\begin{array}{l}1 \\
1\end{array}$ & $\begin{array}{l}1 \\
3\end{array}$ & $\begin{array}{l}1 \\
1\end{array}$ & $\begin{array}{r}1 \\
1 \\
1 \\
1 \\
1 \\
3 \\
15 \\
1 \\
16 \\
1\end{array}$ \\
\hline $\begin{array}{l}\text { Total } \\
\text { Present study }\end{array}$ & & $\begin{array}{l}5 \\
5\end{array}$ & $\begin{array}{r}11 \\
1\end{array}$ & 7 & $\begin{array}{r}53 \\
2\end{array}$ \\
\hline
\end{tabular}


tions at presentation. ${ }^{29}$ It has not been possible to confirm this relationship in our small series of mediastinal teratomas. High concentrations of tumour marker at presentation were not an indication of unresponsiveness or unresectability. This may be because much of the tumour is present in a single mass which is ultimately resected, whereas in the testicular teratomas reported by Germa-Lluch $e t$ $a l^{29}$ marker concentrations were assessed after removal of the primary tumour.

A review of data from published reports shows a median survival of seven months (table 4). Our results are better than this, although numbers are small. They cannot be compared directly with those of the recent series of Hainsworth et al, ${ }^{30}$ who showed prolonged survival in 18 of 31 patients with extragonadal germ cell tumours. Their data do not allow distinction between the patients with mediastinal tumours and with tumours at other sites and their patients include six with seminoma. The improvement in survival reported in the present paper might be attributable to the sequential chemotherapy regimen, which incorporates seven different cytotoxic drugs, including cisplatin ${ }^{31}$ and etoposide. Other important factors are the accurate timing of radical surgery and the use of chemotherapy before operation to reduce tumour bulk.

\section{References}

' Schlumberger HG. Teratoma of the anterior mediastinum in the group of military age. Arch Path 1946;41:398-444.

${ }^{2}$ Ovrum E, Berkefeld S. Mediastinal tumours and cysts. Scand J Thorac Cardiovasc Surg 1979;13:161-8.

${ }^{3}$ Johnson DE, Laneri JP, Mountain CF, Luna M. Extragonadal germ cell tumor. Surgery 1973;73:8590.

${ }^{4}$ Das PB, Bhaktavigian A, Gupta RP et al. Primary malignant tumours of the mediastinum and their management. Aust NZ J Surg 1975;45:42-8.

${ }^{5}$ Dosios T, Sbokos C, McMillan IKR, Mitchell J, Floros D. Primary malignant mediastinal germ cell tumours: a study of three cases. J Surg Oncol 1980;15:367-74.

${ }^{6}$ Rosenberg JC. In: DeVita VT, Hellman S, Rosenberg SA, eds. Cancer - principles and practice of oncology. Philadelphia: Lippincott, 1982:475-96.

${ }^{7}$ Martini N, Golbey RB, Hajdu SI, Whitmore WF, Beattie EJ. Primary mediastinal germ cell tumours. Cancer 1974;33:763-9.

${ }^{8}$ Walden PAM, Woods RL, Fox B, Bagshawe KD. Primary mediastinal trophoblastic teratomas. Thorax 1977;32:752-8.

9 Newlands ES, Begent RHJ, Kaye SB, Rustin GJS, Bagshawe KD. Chemotherapy of advanced malignant teratomas. Br J Cancer 1980;42:378-84.
${ }^{10}$ Huntingdon RW, Bullock WK. Yolk sac tumors of extragonadal origin. Cancer 1970;25:1368.

"Pedersen H. Tumours of the anterior mediastinum. Acta Path Microbiol Scand [A] 1970;212 suppl: 128-42.

12 Pierce GR, Abell MR. Embryonal carcinoma of the testis. Pathol Ann 1970;5:27-60.

${ }^{13}$ Utz DC, Buscemi MF. Extragonadal testicular tumours. J Urol 1971;105:271-4.

${ }^{14}$ Saegesser F, Zoupanos G, Jayet A, Gardiol D. Tumeurs germinales malignes du mediastin. Ann Chir Thorac Cardiovasc 1972;11:71-82.

is Kajita A, Hirokawa K. An autopsy case of endodermal sinus tumor of the anterior mediastinum. Acta Pathol Jpn 1973;23:601.

${ }^{16}$ Sickles EA, Bellieveau RE, Wienik PH. Primary mediastinal choriocarcinoma in the male. Cancer 1974; 33:1196-203.

${ }^{17}$ Cox JD. Primary malignant germinal tumors of the mediastinum. Cancer 1975;36:1162-8.

${ }^{18}$ Diamond SM, Russo JF. Endodermal sinus tumour (yolk sac tumour) of the anterior mediastinum-case report. Milit Med 1976;141:111-4.

${ }^{19}$ Roth LM, Panganiban WG. Gonadal and extragonadal yolk sac carcinomas. Cancer 1976;37:812-20.

${ }^{20}$ De Souet AA, Silver TM, Hart WR. Endodermal sinus tumour of the anterior mediastinum. South Med J 1977;70:757-8.

${ }^{21}$ Mukai K, Adams WR. Yolk sac tumor of the anterior mediastinum. Am J Surg Pathol 1979;3:77-83.

${ }^{22}$ Fox MA, Vix VA. Endodermal sinus (yolk sac) tumors of the anterior mediastinum. Am $J$ Roentgen 1980;135:291-4.

${ }^{23}$ Van Hoesel QGCM, Pinedo HM. Complete remission of mediastinal germ-cell tumors with cisdichlorodiamineplatinum (II) combination chemotherapy. Cancer Treat Rep 1980;64:319-21.

${ }^{24}$ Burt ME, Javadpour N. Germ cell tumors in patients with apparently normal testes. Cancer 1981;47:1911-5.

${ }^{25}$ Economou JS, Trump DL, Holmes EC, Eggleston JE. Management of primary germ cell tumours of the mediastinum. J Thorac Cardiovasc Surg 1982; 83:643-9.

${ }^{26}$ McNeil MM, Leong AS-Y, Sage RE. Primary mediastinal embryonal carcinoma in association with Klinefelter's syndrome. Cancer 1981;47:343-5.

${ }^{27}$ Sogge MR, McDonald SD, Cofard PB. The malignant potential of the dysgenetic germ cell in Klinefelter's syndrome. Am J Med 1979;66:515-8.

${ }^{28}$ Stutzman RE, Donnington G, McAninch JW, Peterson LJ, Scott J, Nachtsheim D. Multiple germ cell tumours: report of three cases, one with three primary lesions. J Urol 1977;117:733-5.

${ }^{29}$ Germa-Lluch JR, Begent RHJ, Bagshawe KD. Tumour marker levels and prognosis in malignant teratoma of the testis. Br J Cancer 1980;42:850-5.

${ }^{30}$ Hainsworth JD, Einhorn LH, Williams SD, Stewart M, Greco FA. Advanced extragonadal germ cell tumors: successful treatment with combination chemotherapy. Proc Am Soc Clin Oncol 1982;1:107.

${ }^{31}$ Vugrin D, Martini N, Whitmore WF, Golbey RB. VAB-3 combination chemotherapy in primary mediastinal germ cell tumours. Cancer Treat Rep 1982;66:1405-7. 